\title{
Larmor-en prezesioa kristaletan gertatzen diren aldaketen detektagailu
}

\section{(Larmor precession: detector for crystalline variations)}

\author{
Irene Urcelay-Olabarria ${ }^{*}$, Josu Mirena Igartua ${ }^{2}$ \\ ${ }^{1}$ Fisika Aplikatua I saila, Bilboko Ingeniaritza Eskola (UPV-EHU) \\ ${ }^{2}$ Fisika Aplikatua II saila, Zientzia eta Teknologia Fakultatea (UPV-EHU) \\ *irene.urcelay@ehu.eus
}

DOI: $10.1387 /$ ekaia.17879

Onartua: 2017-10-18

Laburpena: Material batean gertatzen diren trantsizio magnetikoen eta haren egitura kristalinoaren arteko erlazioa aztertzea oso garrantzitsua da, batik bat multiferroikoak diren materialetan. Gehienetan, trantsizio magnetikoetan gertatzen diren egiturazko aldaketak gako dira trantsizioan agertzen edo desagertzen den polarizazio elektrikoaren jatorria zein den ulertzeko. Hala ere, hainbat materialetan aldaketa horiek oso txikiak dira eta horiek detektatzea oso zaila izan daiteke. Hori da aztergai dugun materialean $\left(\mathrm{MnWO}_{4}\right)$ gertatzen dena. Hori dela eta, ondorio zuzenetara heltzekotan, ezinbestekoa da kristalaren egitura ikertzeko teknika oso sentikorrak erabiltzea. Egiturazko aldaketa oso txikiak aztertzeko neutroien prezesioaz baliatzen den teknika aurkeztuko dugu lan honetan, neutroien bidezko Larmor-en difrakzioa, hain zuzen ere. Nahiz eta lortutako emaitzak behin-behinekoak izan, oso argi ikusten dira zein diren teknika honen indarra eta potentzia, eta trantsizio magnetikoetan gertatzen diren egiturazko aldaketak.

Hitz gakoak: Larmor-en difrakzioa, multiferroikoak, akoplamendu magnetoelastikoa.

\begin{abstract}
The study of the interplay between magnetic transitions and the crystal structure is crucial for the investigation of multiferroic materials. In fact, the structural changes across the magnetic transitions are usually the clue to ascribe the origin of the concomitant appearance of electric polarization. Nevertheless, in some materials, those structural variations are so small that their detection is very difficult. That is the case of $\mathrm{MnWO}_{4}$. Hence, in order to reach appropiate conclusions we need to use experimental techniques which are very sensitive to crystal structure variations. In this piece of work we present an experimental technique that takes profit of the precession of the neutrons in magnetic fields in order to see those small changes in the crystallographic structures, that is, the Larmor diffraction by means of neutrons. Even if the obtained results are rather preliminary, the undoubtedly show the strength and power of this technique and the modifications of the structure across the magnetic transitions.
\end{abstract}

Keywords: Larmor diffraction, multiferroics, magnetoelastic coupling. 


\section{SARRERA}

Bada kontzeptu bat - multiferroizitate, hain zuzen - zientzialari-talde handi bat bere ingurura erakarri duena; batetik, oso garrantzitsua delako egoera solidoaren fisikan eta, bestetik, bera oinarritzat hartuz gara daitezkeen aplikazio teknologikoak direla eta.

Definizioaren arabera, lehen ordenako propietate ferroiko bat baino gehiago aldiberean eta fase berean dituzten materialak dira multiferroikoak. Ferromagnetismoa, ferroelektrizitatea eta ferroelastizitatea dira lehen ordenako propietate ferroikoak ${ }^{1}$, eta propietate horiek dituzten materialetan, magnetizazioa, polarizazio elektrikoa edo deformazioa berezko eran agertzen dira, egonkorrak dira, eta haien noranzkoa modifika daiteke eremu magnetiko, elektriko edo tentsio-eremu bat aplikatuz, hurrenez hurren (ikus 1. irudia). Propietate magnetiko eta elektrikoen artean edozein motatako

$B, E, \varepsilon=0$

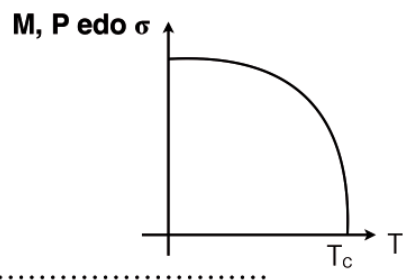

$\mathrm{T}<\mathrm{T}_{\mathrm{c}}$ eta $\mathbf{B}, \mathbf{E}, \boldsymbol{\varepsilon} \neq 0$

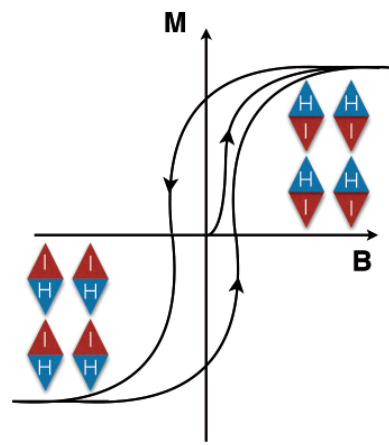

Ferromagnetismoa

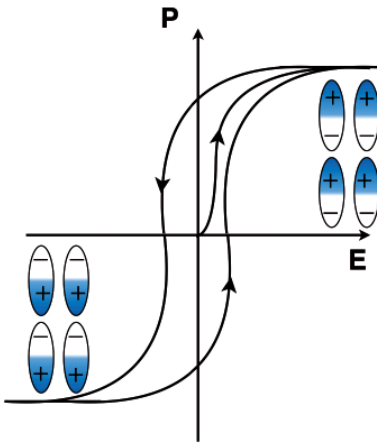

Ferroelektrizitatea

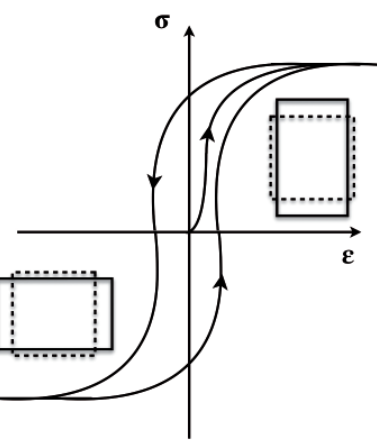

Ferroelastizitatea

1. irudia. Lehen ordenako propietate ferroikoak: ferromagnetismoa, ferroelektrizitatea eta ferroelastizitatea. Propietate horiek dituzten materialetan, tenperatura berezi baten azpitik, magnetizazioa, polarizazio elektrikoa edo deformazioa berezko eran agertzen dira eta egonkorrak dira. Gainera, propietate fisiko horien norabideak alda daitezke eremu magnetiko, elektriko edo tentsio-eremu bat aplikatuz gero.

\footnotetext{
${ }^{1}$ Eztabaidan dago zientzilarien artean ferrotoroidizitatea lehen ordenako propietate denentz.
} 
Larmor-en prezesioa kristaletan gertatzen diren aldaketen detektagailu

akoplamendua duten materialei material magnetoelektriko deritze. Material magnetoelektriko bat aldiberean ferromagnetikoa eta ferroelektrikoa bada, orduan, Material Magnetoelektriko Multiferroikoa (MMM) izango da. Zoritxarrez, ferroelektrizitatearen eta ferromagnetismoaren ezaugarri intrintsekoak sarritan bateraezinak dira eta, ondorioz, MMM materialak oso urriak dira; hau da, naturan ez dira ugariak [1].

Gaur egun, multiferroikoaren definizioa malguagoa da eta, askotan, antiferromagnetikoak (isolatzaileak haiek, gehienetan) eta material ferrimagnetikoak multiferroiko potentzialtzat hartzen dira. Beraz, lehen ordenako propietate ferroikoak ez dira beharrezko; irismen handiko ordena magnetikoa, aldiz, bai. Definizioaren malgutasunak handiagotzen du multiferroikotzat hartzen diren materialen kopurua eta, hortaz, MMM delakoen kopurua ere bai. Normalean, ferroelektrizitatearen eta ordena magnetikoaren arteko erlazioaren araberako bi talde zabaletan sailkatzen dira material multiferroiko magentoelektrikoak: I mota eta II mota [2].

- I mota. Aurkitu ziren lehenengo multiferroikoak izan ziren. Mota honetako multiferroikoetan, ferroelektrizitatearen eta magnetismoaren jatorriak ezberdinak dira, eta era independentean agertzen dira. Gehienetan, polarizazio elektrikoa ordena magnetikoa baino tenperatura altuagoetan agertzen da. Hori dela eta, aplikazio teknologikoetarako ez dira aproposak. Hala ere, tenperatura nahiko altuetan izaten dira multiferroiko (antiferromagnetikoa den $\mathrm{BiFeO}_{3}$ giro-tenperaturan da multiferroiko [3]) eta haien polarizazio elektrikoa ere nahiko handia izaten da. Azken bi ezaugarri horiek material hauen alde egiten dute eta interesgarri bihurtzen dituzte.

- II mota. Talde honetan dauden materialetan, egitura magnetikoak ferroelektrizitatea sorrarazten du. Mota honetako material gehienak tenperatura oso txikietan dira multiferroiko, eta izaten duten polarizazio elektrikoa, I motako materialenarekin alderatuz, oso txikia izaten da. Hala ere, ferroelektrizitatearen eta ordena magnetikoaren lotura oso handia izaten da. Azken hamarkadan aurkitu dira eta haiei esker multiferroikoen arloan interesa berpiztu egin da.

Trantsizio magnetikoen eta kristal-egituren arteko erlazioa aztertzea oinarrizkoa da material multiferroikoen ikerkuntza-prozesuan. Izan ere, trantsizio magnetikoen ondorioz gertatzen diren egiturazko fase-trantsizioak gakoa dira aldiberean agertzen den polarizazio elektrikoaren jatorria finkatzeko. Dena dela, zenbait materialetan, gertatzen diren egiturazko aldaketak hain txikiak dira, ezen haien detekzioa ezinezkoa baita, eta, sarritan, ez dira behatzen. Ondorioz, aztergai dugun materialaren ezaugarri garrantzitsuak bazter batean geratzen dira, eta horrek emaitza okerrak lortzea ekar ditzake. Hori dela eta, ondorio zuzenetara heltzekotan, ezinbestekoa da material horiek egiturazko aldaketekiko oso sentikorrak diren tekniken bidez aztertzea. 
Egiturazko aldaketa oso txikiak aztertzeko neutroien prezesioaz baliatzen den teknika aurkeztuko dugu lan honetan, neutroien bidezko Larmor-en difrakzioa, hain zuzen. Teknika nahiko berria da, eta, nahiz eta oso indartsua den, nahiko ezezaguna da oraindik ere $[4,5,6]$. Gainera, lan honetan $\mathrm{MnWO}_{4}$ materialaren, II motako multiferroikoaren, kristal-egitura aztertuko dugu. Lehendabizi, neutroien bidezko difrakzio arrunta erabili da eta, emaitzak ikusita, Larmor-en difrakzio izeneko teknikaz baliatuko gara, zeina askoz ere sentikorragoa baita. Nahiz eta lortutako emaitzak behin-behinekoak izan, oso argi ikusten da zenbateko potentziakoa eta indarrekoa den teknika.

\section{ESPERIMENTAZIO-TEKNIKA}

Nahiz eta gaur egungo aurrerakuntza teknologikoek ahalbidetzen duten zientzialariek hamaika teknikaren bidez materialak azter ditzaten, oraindik ere oso zaila da ikustea kristal batean dauden atomoak. Askotan, haiek ikusi ahal izateko, zeharkako metodoak erabiltzen dira, difrakzioa, besteak beste. Difrakziozko esperimentuetan gertatzen diren uhinen eta kristaletako atomoen konfigurazio ordenatuen arteko elkarrekintzak sorrarazitako difrakzio-patroiak aztertuz posiblea da berreraikitzea materialaren kristalegitura.

William Henry Bragg-ek eta haren semeak, William Lawrence Bragg-ek, 1913. urtean ondorioztatu zuten ezen, difrakzio-sarea kristala den kasuan, interferentzia eraikitzailea gertatzeko baldintza honako hau zela:

$$
n \lambda=2 d \sin (\theta)
$$

Adierazpen horri Bragg-en legea deritzo eta, horretan, $n$ da difraktatutako izpiaren ordena, zenbaki osoa bera; $\lambda$, erradiazioaren uhin-luzera [ikus 2(a) irudia]; $d$, planoen arteko distantzia; eta $\theta$, difraktatutako izpiaren eta izpi erasotzailearen arteko angeluaren erdia. Lege honen irudi grafikoa 2(b) irudian ikus daiteke. Bragg-en legeak dioena zera da: plano mota berberetik datozen izpi difraktatuen arteko bide-diferentzia uhin-luzeraren multiplo denean, izpi difraktatuen arteko interferentzia eraikitzailea izango da eta islapen-puntu bat izango dugu. Beraz, kristal bati uhin apropos batekin erasotzean, $\theta$ angelu berezi batzuetarako islapen-puntuak izango ditugu eta horiek puntuz osatutako sare bat sortzen dute. Beraz, sareko puntuak aztertuz, atomo-planoen arteko distantziak ondoriozta daitezke, eta baita gelaxka-unitatearen ${ }^{2}$ parametroak ere. Difrakzio-puntu horien intentsitatea, ordea, lotuta dago gelaxkaren barneko atomoen kokapenarekin.

\footnotetext{
2 Egitura kristalinoan errepikatzen den unitatea da gelaxka-unitatea. Gelaxka-unitatea hiru dimentsiotan trasladatuz kristal osoa eraikitzen da.
} 
Izpi erasotzailearen eta difraktatutako izpiaren uhin-bektoreak $\mathbf{k}_{i}$ eta $\mathbf{k}_{f}$ izanik, Bragg-en legea beste era honetan ere adieraz daiteke:

(a)

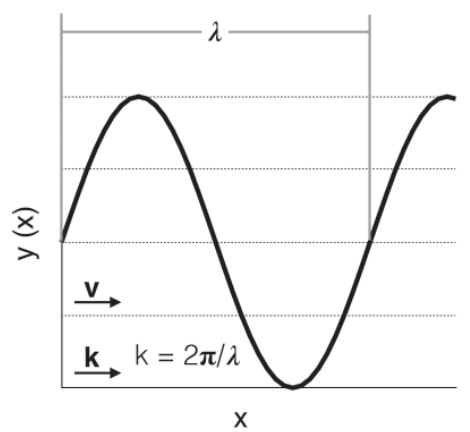

(b)

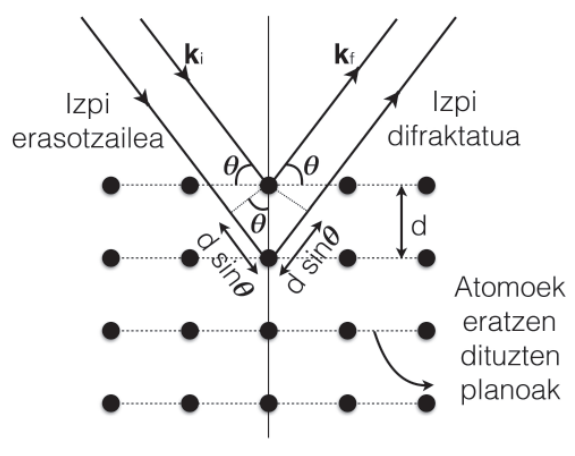

2. irudia. (a) $x$ ardatzaren norabide positiboan $\mathbf{v}$ abiaduran hedatzen den uhina adierazten da. Horretan, uhinaren uhin-luzeraren adierazita dago, eta uhin-luzeraren eta uhin-bektorearen arteko erlazioa ere bai. (b) Bragg-en legearen eskema, zeinean bi plano berdinetan erasotzen duten eta horietatik difraktatuta ateratzen diren izpien arteko bide optikoaren diferentzia adierazten den, $2 d \sin \theta$. Bide optikoaren diferentzia izpiaren uhin-luzeraren multiplo osoa bada, $n \lambda$, difraktatutako izpiek interferentzia eraikitzailea sortuko dute eta difrakzio-puntu bat lortuko da.

$$
G=2 k \sin \theta
$$

edo

$$
\frac{G}{2}=k \sin \theta=k_{\perp},
$$

non $G$ baita difrakzio-puntuek eratzen duten sareko bi punturen arteko bektorearen modulua. $\mathbf{G}$ bektorea perpendikularra da difraktatzen ari diren atomo-planoekiko, eta haren modulua planoen arteko $d$ distantziarekin erlazionatuta dago: $2 \pi / d$. Kontuan hartu difrakzioa elastikoa denez ez dagoela energia transferentziarik izpi erasotzailearen eta kristalaren artean; ondorioz, izpi erasotzailearen eta difraktatutakoaren energiak berdinak dira, eta $\mathbf{k}_{i}$ eta $\mathbf{k}_{f}$ bektoreen moduluak, berdinak, $k$.

Hainbat izpi motarekin egin daiteke difrakzioa: X izpiak, elektroiak eta neutroiak. Izpi motaren araberakoa da jasotzen den informazioa. Neutroien propietateei esker bete ditzakegu gure helburuak, material multiferroikoei dagokienez. Termalizatutako neutroien masari dagokion de Broglie-ren uhin-luzera eta kristal-egituretako atomoen arteko distantziak parekoak 
dira eta hori funtsezkoa da difrakzio-baldintza bete dadin. Horrez gain, neutroia neutroa da eta, ondorioz, ez du elkarrekintza elektrikorik lagineko elektroiekin. Are gehiago, sakon sar daiteke laginean eta, beraz, gainazaleko informazioa ez ezik, bolumenekoa ere eman dezake. Eta, azkenik, neutroiak momentu magnetikoa dauka; horrek dipolo-dipolo elkarrekintza du materialeko atomoetako elektroi parekatu gabeekin. Hortaz, neutroiak oso egokiak dira ez soilik materialen kristal-egiturak aztertzeko, baizik eta haien egitura magnetikoa finkatzeko ere bai. Ez hori bakarrik: neutroi-izpia polarizatu egin daiteke. Arestian esan bezala, neutroiak momentu magnetikoa dauka. Neutroi-izpia guztiz polaritzatuta dagoela esaten da izpia osatzen duten neutroi guztien momentu magnetikoak norabide eta noranzko berberekoak direnean. Azken ezaugarri hori ezinbestekoa da Larmor-en difrakzioa deritzon teknika aurrera eramateko.

\subsection{Larmor-en difrakzioa}

Teknika hau Rekveldt-ek garatu zuen orain dela 15 urte $[4,5,6]$. Larmor-en prezesioan oinarritzen da: eremu magnetiko batean dagoen spinak edo momentu magnetikoak prezesatu egiten du eremu magnetikoaren norabidearen inguruan [ikus 3(a) irudia]. Prezesioaren maiztasuna da Larmor-en maiztasunaren berdina da; honako hau:

$$
\omega_{L}=-\frac{e g}{2 m} B
$$

Adierazpen horretan, $B$ da eremu magnetikoaren modulua; $g$, partikularen momentu magnetikoa eta faktore giromagnetikoa erlazionatzen dituen $g$ faktorea, eta $m$, prezesatzen duen horren masa, neutroiarena kasu honetan.

(a)

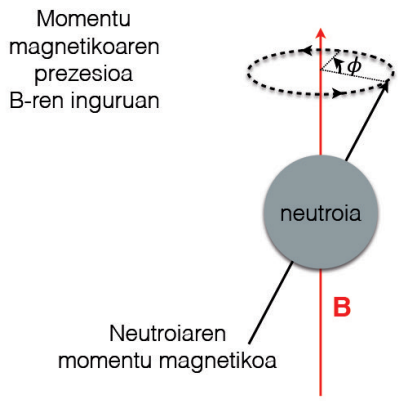

(b)

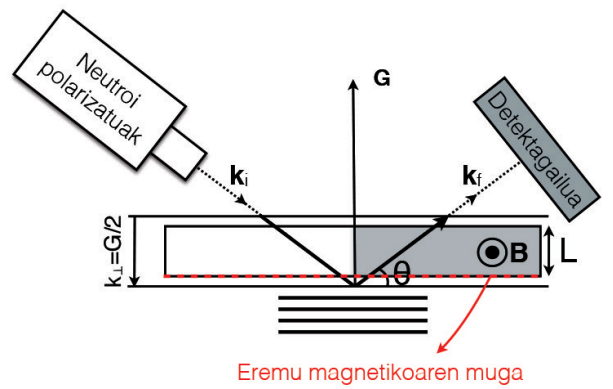

3. irudia. (a) Larmor-en prezesioaren adierazpen grafikoa. (b) Difrakzioa gertatu aurretik eta ondoren, neutroiak ibilbide berdina egiten du haril bakoitzaren barruan, eta, beraz, prezesio berbera egingo du haril bakoitzean. 
Larmor-en prezesioa kristaletan gertatzen diren aldaketen detektagailu

Klasikoki aztertuz, onar dezagun $v$ abiadurako neutroiak daudela izpi erasotzailean eta gainera neutroi guztien momentu magnetikoak norabide eta norantza berberean daudela orientatuta, hau da, izpi erasotzailea polarizatuta dagoela. Izpi hori eremu magnetikodun haril batetik pasarazten da [3(b) irudiko haril txuria]. Ondoren, laginaren kontra talka egiten du izpiak eta, azkenik, bigarren harilean zehar ihes egiten du [3(b) irudiko harila grisa], eta detektagailura iristen da. Izpi erasotzailearen polarizazioa eta eremu magnetikoa perpendikularrak dira. Gainera, eremu magnetikoaren muga eta atomo-planoak paraleloak dira [ikus 3(b) irudia]. Neutroiek, haril bakoitza zeharkatzeko, $t$ denbora behar dute. Hortaz, neutroien momentuek haril bakoitzean betetzen duten $\phi$ prezesio-angelua $t$ denboraren eta Larmor-en maiztasunaren biderkadura izango da:

$$
\phi=\omega_{L} t=\omega_{L} \frac{L}{v_{\perp}} .
$$

Kontuan izan behar da ezen neutroiek, eremu magnetikoan sartzen direnean, eremu horren mugekiko $\theta$ angelua eratzen dutela; ondorioz, Larmor-en prezesioa da eremu magnetikoaren mugekiko perpedikularra den abiaduraren funtzioa. $L$, beraz, laginaren atomo-planoekiko perpendikularra den eremu magnetikoaren luzera da. Konfigurazio honetan [3(b) irudia], neutroiek $L$ luzera berbera zeharkatzen dute. Kontuan hartuta ez dela abiaduraren aldaketarik gertatzen eta abiadura $v=\frac{p}{m}=\frac{\hbar k}{m}=\frac{\hbar 2 \pi}{\lambda m}$ dela, eta (2) ekuazioa, bi hariletatik pasatu ondoren neutroiek betetzen duten prezesio-angelua honako hau da:

$$
\begin{aligned}
\phi=\frac{2 \omega_{L} L}{v_{\perp}} & =\frac{2 \omega_{L} L m}{\hbar k \sin \theta} \quad \text { edo } \\
& =\frac{2 \omega_{L} L m}{\pi \hbar} d
\end{aligned}
$$

Hortaz, neutroien prezesio osoa neurtuz gero, atomo-planoen arteko distantziak kalkula daitezke.

Nahiz eta eremu magnetikoaren muga eta plano difraktatzailea elkarrekiko perpendikularrak izan ez, teknika honek gelaxka-parametroak zehaztasun oso handiz kalkulatzea ahalbidetzen du.

Beraz, neutroiek hariletan zehar egindako prezesio-angelua edo fasea neurtuz, gelaxka-konstanteen aldaketak, zabaltze eta uzkurtze termikoen ondoriozkoak haiek, bereizmen izugarri handiz lortu daitezke, kristaleko atomo-planoen orientazio-aldaketa txikiak egon arren. 


\section{AZTERGAI DEN MATERIALA: $\mathrm{MnWO}_{4}$}

$\mathrm{MnWO}_{4}$ konposatuaren kristal-egituraren simetria $P$ 2/c da (13. Zb., $b$ ardatz berezia, ohiko setting-a); [100] norabidean zeharreko Mn eta W atomoz osatutako aldizkako geruzek osatutako kristal-egitura gisa deskriba daiteke. Oxigeno atomoek arras distortsio-natutako oktaedroak osatzen dituzte $\mathrm{Mn}$ eta $\mathrm{W}$ atomoen inguruan eta, gainera, oktaedroek alde bana partekatzen dute aldamenekoekin. Horrela, sigi-saga moduko kateak eraikitzen dituzte oktaedroek $c$ ardatzean zehar (ikus 4. irudia) [7,8].

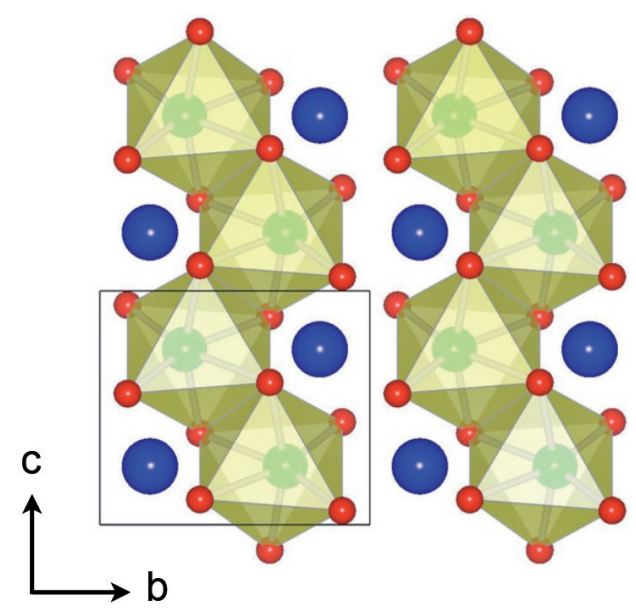

4. irudia. Kristal-egituraren proiekzioa, $a$ ardatzean zehar. Wolframio atomoak adierazten dituzte zirkulu urdinek; oxigeno atomoak, gorriek; eta manganeso atomoak, berdeek.

Bero-ahalmen espezifikoko esperimentuek, C.P. Landee-k eta E.R. Westrum-ek [9] egindakoek, hiru anomalia agerrarazi zituzten honako tenperatura hauetan: 6,8(1) K, 12,57(5) K eta 13,36(5) K. Hirurak lotu ziren elkarren segidako trantsizio magnetikoekin. Honako izen hauek esleitu zitzaien fase magnetikoei: AF3, (13,5 $\mathrm{K} \lesssim \mathrm{T} \lesssim 12,5 \mathrm{~K})$ tartekoari; $\mathrm{AF} 2$, $12,5 \mathrm{~K} \lesssim \mathrm{T} \lesssim 6,8 \mathrm{~K})$ tartekoari eta $\mathrm{AF} 1(\mathrm{~T} \lesssim 6,8 \mathrm{~K})$ tartekoari.

Aipatutako faseetako spin-konfigurazioak Lautenschläger-ek eta laguntzaileek zehatz-mehatz aztertu zituzten [10]. Néel-en tenperaturatik behera, $\mathrm{T}_{N} \approx 13,5 \mathrm{~K}$ tenperaturan hain zuzen, $\hat{u}$ norabidearekin bat eginez lerrokatzen dira momentu magnetikoak, $a c$ planoan, era sinusoidalean modulatutako anplitudea eta hedatze-bektore komentsuraezina dituztela: $\mathbf{k}=(-0,214,1 / 2,0,457)$ [AF3 fase magnetikoa, 5(a) irudian ikus daitekeenez]. 
(a)

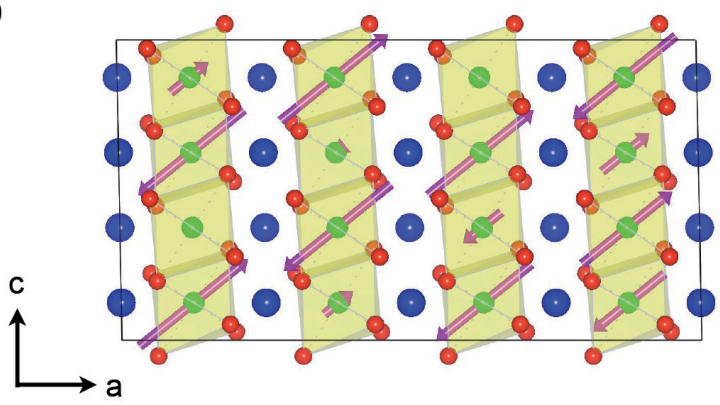

(b)

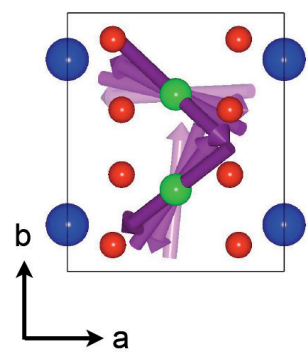

(c)

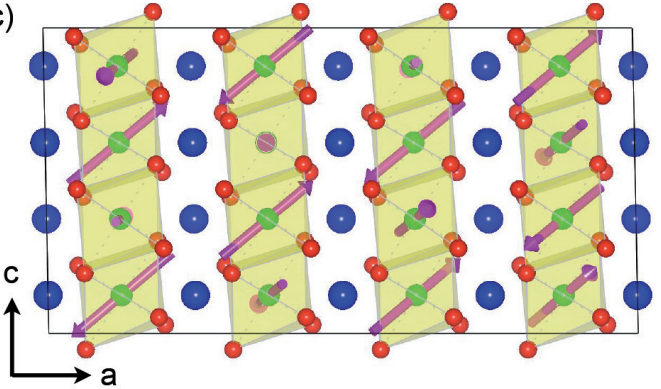

(d)

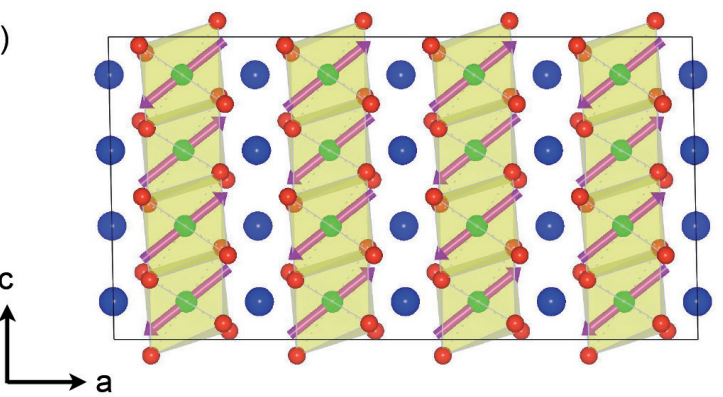

5. irudia. Lautenschläger-ek eta laguntzaileek [10] lortutako $\mathrm{MnWO}_{4}$ konposaturen egitura magnetikoak: (a) AF3 egitura magnetikoa, $b$ ardatzean zeharrekoa; (b) AF2 egitura magnetikoa, $c$ ardatzean zeharrekoa: argia da, oso, momentuen biraketa, (c) aurreko egitura berbera, $b$ ardatzean zeharreko proiekzioan; (d) AF1 spin-konfigurazio komentsuragarria.

Esan denez, $\hat{u}$ norabidea, ardatz erraz magnetikoa bera, $a c$ planoan dago eta $35^{\circ}$ angelua eratzen du $a$ ardatzarekin. AF2 fasea $12,5 \mathrm{~K}<\mathrm{T}<7,5 \mathrm{~K}$ tartean agertzen da eta $b$ ardatzean zeharreko osagai magnetiko gehigarria dauka. Fase honetan hedatze-bektorea mantentzen da. Hortaz, orde- 
namendu magnetikoa da zikloide eliptikoa den spin-egitura, 5 (b) irudian adierazi den moduan. 7,5 K-eko tenperaturatik behera, honako era honetan deskriba daiteke sistema: $\hat{u}$ norabidearekiko kolineala eta komentsuragarria, $\mathbf{k}=( \pm 1 / 4,1 / 2,1 / 2)$ hedatze-bektorearekin [ikus 5(c) irudia].

Material hau aztertzeko jakin-minak gora egin du nabarmenki azken urteotan, material honek tenperatura txikietan izaera ferroelektrikokoa ere bazuela ikusitakoan, bereziki, gainera, propietate hori arras lotuta agertu baita ordena magnetikoari $[11,12]$. AF2 egitura magnetikoa hedatuta dagoen tenperatura-tartean, $b$ ardatzean zeharreko polarizazio elektrikoa behatu zen eta, ondorioz, AF2 zikloide egitura II motako fase multiferroikoa da.

Maiz, kristal-egituren distortsioak gertatzen dira trantsizio magnetikoak gertatutakoan; efektu magnetoelastiko edo spin-sare akoplamendua deritzo horri $[13,14,15]$. $\mathrm{MnWO}_{4}$ konposatuaren kasuan, aipatutako fenomenoa oso ahula da; hots, ardatz kristalografikoetan behatutako aldaketa erlatiboak $\Delta L / L \sim 10^{-5}$ ordenakoak dira, [16]-ren arabera. Zabaltze termikoaren bidezko esperimentuen bidez behatu ziren aldaketa txiki horiek; haietan, $a$ ardatzak adierazi zuen trantsizioekiko sentikortasun handiena.

Lan honetan ikusiko dugu nola neutroien prezesioren propietatea erabiliz $\Delta L / L \sim 10^{-6}$ ordenako aldaketak ere oso agerian ikus daitezkeen.

\section{TRANTSIZIO MAGNETIKOETAN ZEHARREKO MnWO KRISTAL-EGITURAREN AZTERKETA, MONOKRISTALEZKO NEUTROIEN BIDEZKO DIFRAKZIOA ERABILITA}

$\mathrm{MnWO}_{4}$ konposatu puruaren kristal-egitura kontu handiz aztertu zen neutroien bidezko difrakzio-esperimentuen bidez, Grenoble-n (Frantzian) dagoen Institute Laue-Langevin-eko (ILL) D15 tresnan. Esperimentua lau zirkuluko geometria erabiliz egin zen.

Kristal-egiturak findu ziren $T=2 \mathrm{~K}, 5 \mathrm{~K}, 8 \mathrm{~K}$ tenperaturetan (magnetikoki ordenatutako egoeretan) eta $T=16 \mathrm{~K}$ tenperaturan (egoera paramagnetikoan). Tenperatura horietan, gelaxka-parametroak lortu ziren ( $a, b, c$ eta $\beta) ; 1$. taulan zerrendatuta daude parametroak. Ez zen behatu inolako aldaketa esanguratsurik gelaxka-parametroetan.

Trantsizio magnetikoetan, gelaxkaren aldaketaz gain, kristal-egituraren aldaketak gerta daitezke. Hala ere, neutroien bidezko difrakzioan jasotako datuak erabiliz egiturak fintzean, ez zen inolako aldaketarik behatu atomoen posizioetan tenperatura horietan.

Beraz, esperimentuaren bereizmena kontuan harturik, ez dago egitura-aldaketa argirik $\mathrm{MnWO}_{4}$ konposatuan. Oktaedroak arras distortsionaturik daude, baina ordena magnetikoak ez dauka eraginik aipatutako distortsioan. 
Larmor-en prezesioa kristaletan gertatzen diren aldaketen detektagailu

1. taula. Monokristalezko neutroien bidezko difrakziozko datuak finduz lortutako $\mathrm{MnWO}_{4}$ konposatuaren kristal-egituraren parametroak, $16 \mathrm{~K}, 8 \mathrm{~K}, 5 \mathrm{~K}$ eta $2 \mathrm{~K}$ tenperaturetan. Koordenatu atomikoak gelaxkarekiko erlatiboak dira. Esperimentu denak egin dira D15 tresnan eta 4-zirkuluko geometria erabiliz.

\begin{tabular}{ccrrr}
\hline $\begin{array}{c}\text { Tenperatura } \\
\text { Fase Magnetikoa }\end{array}$ & $\begin{array}{c}T=16 \mathrm{~K} \\
\text { Paramagnetikoa }\end{array}$ & \multicolumn{1}{c}{$\begin{array}{c}T=8 \mathrm{~K} \\
\mathrm{AF} 2\end{array}$} & \multicolumn{1}{c}{$\begin{array}{c}T=5 \mathrm{~K} \\
\mathrm{AF} 2-\mathrm{AF} 1\end{array}$} & \multicolumn{1}{c}{$\begin{array}{c}T=2 \mathrm{~K} \\
\mathrm{AF} 1\end{array}$} \\
\hline$a / \AA$ & $4,824(2)$ & $4,823(2)$ & $4,824(2)$ & $4,824(2)$ \\
$b / \AA$ & $5,755(3)$ & $5,755(3)$ & $5,757(2)$ & $5,756(2)$ \\
$c / \AA$ & $5,002(2)$ & $5,001(3)$ & $5,004(2)$ & $5,004(2)$ \\
$\beta /{ }^{\circ}$ & $91,080(3)$ & $91,100(4)$ & $91,090(2)$ & $91,060(3)$ \\
Bolumena/ $/ \AA^{3}$ & $138,830(3)$ & $138,790(4)$ & $138,980(2)$ & $138,950(3)$ \\
\hline
\end{tabular}

Bi gauza gerta daitezke kasu honetan: benetan ez dagoela inolako kristal-egituraren inolako aldaketarik, edota azterketa egiteko erabili den teknikaren sentikortasuna ez dela nahikoa aldaketa horiek detektatzeko. Segidan ikusiko denez, bigarren hipotesia da zuzena.

\section{LARMOR-EN DIFRAKZIOAREN BIDEZKO AKOPLAMENDU MAGNETOELASTIKOAREN DETEKZIOA}

Gelaxka-parametroen aldaketa txikiak behatzeko asmotan, Larmor-en difrakzioko konfigurazioan antolatutako spin-oihartzun motako esperimetua egin genuen. Termalizatutako neutroiak erabiltzen dituen hiru ardatzeko IN22 espektrometroan egin genuen (ILL zentrokoa) esperimentua. Tresna ez zegoen optimizatua, eta egindako esperimentuak behin-behineko emaitzak eman zizkigun. Hala ere, teknikaren potentzia uzten dute agerian emaitzek eta, gainera, akoplamentu magnetoelastikoa erakusten dute.

Datuak jaso ziren tenperatura txikitzean ( $a$ parametroarenak) eta handitzean ( $b$ parametroarenak). Lortutako parametroen aldaketak oso-oso txikiak dira: $\Delta a / a \sim 10^{-5}$ eta $\Delta b / b \sim 10^{-6}$. Hau da, $a$ parametroa $\sim 4,8 \AA$-ekoa izanik, lortzen ditugun aldaketak $10^{-5} \AA$-ekoak dira eta $b$ parametroaren kasuan $10^{-6} \AA$-ekoak, benetan oso-oso aldaketa txikiak dira, femtometroen ordenakoak.

Parametroen aldakuntzen eboluzioek $(\Delta a / a$ eta $\Delta b / b)$ nabariak diren aldaketak jasaten dituzte trantsizio magnetikoak gertatzen diren tenperaturetan: $T_{1} \approx T_{N}$ eta $T_{2} \approx T_{A F_{2}-A F_{1}}$, hurrenez hurren. Datuak eta trantsizioetan gertatzen diren aldaketak 6 . irudian adierazi dira. Gainerako parametroak $(c$ eta $\beta$ ) ez ziren aztertu.

Aldaketa nabarmena a gelaxka-parametroaren eboluzioan gertatzen da. Tenperaturak behera egin ahala $a$ parametroa txikiagotuz doa, espero 


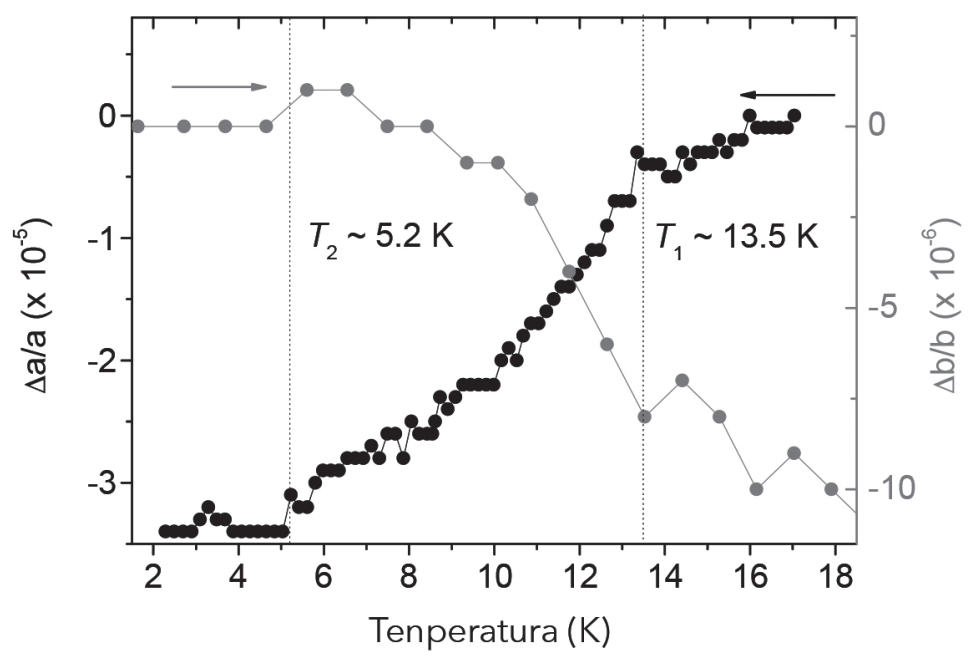

6. irudia. (a) Larmor difrakzioaren bidez ikusitako $a$ eta $b$ gelaxka-parametroen aldaketa erlatiboak.

zenez, baina txikiagotze-erritmoa oso ezberdina da fase magnetiko bakoitzean: AF2 fasean, zeina multiferroikoa baita, txikiagotze-erritmoa handiena da. Fenomeno hori guztiz lotuta dago momentu magnetikoen arteko elkarrekintzekin [17]. $a$ parametroaren norabidean dauden bi Mnkateren arteko elkarrekintza magnetikoa gehienbat antiferromagnetikoa da, eta nahiko bizia; horren ondorioz, momentu magnetikoen arteko indar erakarleak gerta daitezke eta horrek $a$ parametroa txikiagotzea eragin dezake. Bestalde, $b$ parametroaren norabidean dauden kateen artean, elkarrekintza nagusia ferromagnetikoa da, eta ahula. Hori dela eta, kate horien arteko indarrak, gehienbat, aldaratzaileak izan daitezke eta, beraz, $b$ parametroa hazi egiten da. Horrela azal liteke bi parametro horien eboluzioaren eitea.

Parametro horiek tenperaturarekiko agertzen duten eboluzioa bat dator [16] erreferentziakoarekin: tenperatura txikiagotzen denean, $b$ handiagotu egiten da, zertxobait, eta $a$ txikiagotu egiten da, $b$-ren aldaketa erlatiboa txikiago izanik, nahiz eta Chaudhury-ek eta laguntzaileek argitaratutako lanarekin alderen bat dagoen parametroen aldaketa absolutuei dagokienez. Halere, gelaxka-parametroen aldaketa txikiak baieztatzen du, batetik, badagoela akoplamendu magnetoelastikoa eta, bestetik, neutroien bidezko monokristalen ohiko difrakzio-esperimentuak, D15 tresnan egidakoaren modukoak, ez direla aztertu nahi izan diren efektu horiek benetan hautemateko bezain sentikorrak. 
Larmor-en prezesioa kristaletan gertatzen diren aldaketen detektagailu

\section{ONDORIOAK}

$\mathrm{MnWO}_{4}$ material multiferroikoa erabili dugu Larmor-en difrakzioa aurkezteko eta honen erabilgarritasuna eta sentikortasuna erakusteko.

Lan honetan aztertutako $\mathrm{MnWO}_{4}$ materialak hiru trantsizio magnetiko ditu; tenperaturak behera egiten duenean, ordena honetan ageri dira: fase paramagnetikotik AF3 fasera, AF3-tik AF2-ra eta AF2-tik AF1-era. Egitura magnetiko horiekin eta batetik besterako trantsizioekin lotutako efektu magnetoelastikoa baieztatzeko, bi metodo erabili dira: neutroien bidezko difrakzio arrunta eta Larmor-en difrakzioa, biak monokristala erabiliz egindakoak.

Neutroien bidezko difrakzio arrunta monokristalean egindakoan eta lortutako emaitzen arabera, errore esperimentala kontuan hartuz, egitura kristalinoak ez du inolako aldaketarik jasaten tenperatura txikitu ahala eta fasetrantsizioak zeharkatzean.

Larmor-en difrakzioak, ordea, agerian uzten ditu $a$ eta $b$ gelaxka-parametroetan gertatzen diren aldaketak. Aldaketa nabarmena $a$ gelaxka-parametroan gertatzen da.

Tenperaturak behera egin ahala, $a$ parametroa txikiagotuz doa, espero zenez, baina txikiagotze-erritmoa oso ezberdina da fase magnetiko bakoitzean. Hori ulertzeko, egitura magnetikoari so egin behar zaio: $a$ parametroaren norabidean dauden bi Mn-kateren arteko elkarrekintza, gehienbat, antiferromagnetikoa da, eta nahiko bizia; $b$ parametroaren norabidean daudenen artekoa, ordea, ferromagnetikoa eta ahula. Horrek azal dezake bi parametro horien eboluzioa. Ondorioz, atomoen artean gerta daitekeen indar erakarleak edo aldaratzaileak gelaxka-parametroen uzkurtzea edo zabaltzea eragin dezake.

Aldaketa kantitateari erreparatzean, horiek oso txikiak dira, $\Delta L / L \sim$ $\left(10^{-5}-10^{-6}\right)$ ordenakoak haiek, baina, hala ere, teknika honen bidez argi eta garbi detektatu ahal izan dira.

Horrela, Larmor-en difrakzioaren indarra ikusi dugu haren sentikortasunari erreparatuz. Neutroien momentu magnetikoa birarazten jarriz eta honek egiten dituzten biren kopurua aztertuz kristalaren gelaxka-parametroak lortu ditugu zehaztasun handiz, eta efektu magnetoelastikoa baieztatu ahal izan dugu.

\section{ESKER ONAK}

Autoreek Institute Laue Langevin erakundeari eskerrak eman nahi dizkiote, bertan neutroien bidezko difrakzio-esperimentuak egiteko emandako denboragatik. Baita E. Ressouche-i, N. Martin-i eta L.P. Regnault-i 
ere, esperimentua eta datuen tratamentua haien gidaritzapean egin zelako. Era berean, autoreek eskerrak eman nahi dizkiete Espainiako Ekonomia eta Lehiakortasuna Ministerioari eta FEDER fondoei (proiektu-zenbakia: MAT2015-66441-P) haiei esker lan hau aurrera atera ahal izan dutelako.

\section{BIBLIOGRAFIA}

[1] Nicola A. Hill. 2000. J. Phys. Chem. B 104, 6694-6709.

[2] D. Khomskii. 2009. Physics 2, 20.

[3] W. Eerenstein, N. D. Mathur and J.F. Scott. 2006. Nature 442, 759.

[4] Rekveldt M.T., Keller T., Kraan W.H. 2001. Ellrophys. Lett, 54, 342-346.

[5] Rekveldt M.T. 2000. Mater. Sci. Forum, 321-324, 258-263.

[6] Rekveldt M.T., Kraan W.H., and Keller T. 2001. Journal of Applied Crystallography, 35, 28-33.

[7] Y.P. Simanov and R.D. Kurshakova. 1957. Zhurnal Fizicheskoi Khimii, 31, 820-824.

[8] H. Weitzel. 1976. Z. Kristallogr. 144, 238.

[9] C.P. Landee and E.F. Westrum, in Magnetism and Magnetic Materials. 1975. Proceedings of the $21^{\text {st }}$ Annual Conference on Magnetism and Magnetic Materials, edited by D. C. Graham and J. J. Thyne, AIP Conf. Proc. No. 29 (AIP, New York, 1976), pp. 445-446; 1976. J. Chem. Thermodyn. 8, 663.

[10] G. Lautenschl“ager, H. Wietzel, T. Vogt, R. Hock, A. Bhm and H. Fuess. 1993. Phys. Rev. B 48, 6087.

[11] O. Heyer, H. Hollmann, I. Klassen, S. Jodlauk, L. Bohaty`, P. Becker, J.A. Mydosh, T. Lorenz and D. Khomskii. 2006. J. Phys.: Condens. Matter 18 L417-L475.

[12] A. H. Arkenbout, T. T. M. Palstra, T. Siegrist, and T. Kimura. 2006. Phys. Rev. B 74, 184431.

[13] C. dela Cruz, F. Yen, B. Lorenz, Y. Q. Wang, Y. Y. Sun, M. M. Gospodinov and C.W. Chu. 2005. Phys. Rev. B 71, 060407(R).

[14] Seongsu L., A. Pirogov, Misun Kang, Kwang-Hyun Jang, M. Yonemura, T. Kamiyama, S.-W. Cheong, F. Gozzo, Namsoo Shin, H. Kimura, Y. Noda and J.-G. Park. 2007. Nature 451, 805-808.

[15] H.C. Walker, F. Fabrizi, L. Paolasini, F. de Bergevin, J. Herrero-Martin, A.T. Boothroyd, D. Prabhakaran, D.F. McMorrow. 2011. Science 333, 1273.

[16] R.P. Chaudhury, F. Yen, C.R. de la Cruz, B. Lorenz, Y.Q. Wang, Y.Y. Sun, C.W. Chu. 2008. Physica B 403 1428-1430.

[17] F. Ye, R.S. Fishman, J.A. Fernandez-Baca, A.A. Podlesnyak, G. Ehlers, H.A. Mook, Y. Wang, B. Lorenz and C.W. Chu. 2011. Phys. Rev. B 83, 140401. 